\title{
Markets, Morals, and Practices of Trade: Jurisdictional Disputes in the U.S. Commerce in Cadavers
}

\section{Citation}

Anteby, Michel. "Markets, Morals, and Practices of Trade: Jurisdictional Disputes in the U.S.

Commerce in Cadavers." Administrative Science Quarterly 55, no. 4 (December 2010): 606-638.

\section{Published Version}

http://asq.sagepub.com/content/55/4/606.abstract

\section{Permanent link}

http://nrs.harvard.edu/urn-3:HUL.InstRepos:12748547

\section{Terms of Use}

This article was downloaded from Harvard University's DASH repository, and is made available under the terms and conditions applicable to Open Access Policy Articles, as set forth at http:// nrs.harvard.edu/urn-3:HUL.InstRepos:dash.current.terms-of-use\#OAP

\section{Share Your Story}

The Harvard community has made this article openly available. Please share how this access benefits you. Submit a story.

Accessibility 
Markets, Morals, and Practices of Trade:

Jurisdictional Disputes in the U.S. Commerce in Cadavers

\author{
Michel Anteby \\ Harvard University
}

Published in Administrative Science Quarterly, 2010, 55 (4), 606-638.

- Uncorrected Proofs - 


\title{
Markets, Morals, and Practices of Trade: \\ Jurisdictional Disputes in the U.S. Commerce in Cadavers
}

\begin{abstract}
This study examines the U.S. commerce in human cadavers for medical education and research to explore variation in legitimacy in trades involving similar goods. It draws on archival, interview, and observational data mainly from New York State to analyze market participants' efforts to legitimize commerce and resolve a jurisdictional dispute. Building on literature on professions, the study shows that how goods are traded, not only what is traded, proves integral to constructing legitimacy, thus suggesting a practicebased view of moral markets. The professionals, including a group of "gatekeepers," construct a narrative distinction between their own commerce and an implicitly less moral alternative and geographically insulate their trades from the broader commerce; creating in effect two circuits. Yet the professionals also promote specific practices of trade within their circuit to help them distinguish their own pursuit from an alternative course of action. The study's findings shed light on the micro-foundations of market legitimization and on the role of morals in sustaining professional jurisdictions.
\end{abstract}


The notion that markets permeate society is nothing new; scholars have long noted the pervasiveness of markets in society (Zelizer, 1979; Hirschman, 1982; FourcadeGourinchas and Healy, 2007; Sandel, 2009). Yet the development of legal markets for "goods" previously deemed off-limits to trade, such as human life and death, has proven surprising and raised anew the question of morals and markets. Despite calls for banning commerce in many goods, particularly human anatomical goods like blood, cadavers, and organs (Titmuss, 1971; Scheper-Hughes, 2000; Delmonico et al., 2002; Healy, 2004; Sanal, 2004; Steiner, 2006), the gradual emergence of such commerce testifies to the growing reach of markets. For instance, selling one's eggs, plasma, or sperm is a fairly common and legal practice in the United States today (Snow and Anderson, 1993: 65-66; Almeling, 2007). The legality of commerce does not, however, imply moral legitimacy; instead, it brings new urgency to the question of what makes markets moral.

A main insight from the institutional literature is that an institution's structural features are integral in defining its legitimacy (Meyer and Rowan, 1977; Scott, 1977; Zucker, 1986; Scott, 1992). Put otherwise, an institution is deemed "valuable and worthy of support because its structural characteristics locate it within a morally favored taxonomic category" (Suchman, 1995: 581). By extending this insight to markets, scholars have shown that markets are often deemed morally legitimate or illegitimate depending on the category of traded goods (Spar, 2006; Almeling, 2007; Quinn, 2008; Satz, 2010). Knowing, for instance, that a car or a life is being traded is often seen as a sufficiently defining feature in passing moral judgment. At the same time, the actual doing of commerce or the micro-foundations of legitimacy tend to go unexamined (Hallett and 
Ventresca, 2006; Powell and Colyvas, 2008). Thus what makes markets moral essentially hinges on the category of traded goods.

Though the strategic view of legitimacy offers a different answer to the question of morals and markets (Pfeffer and Salancik, 1974; Dowling and Pfeffer, 1975; Ashforth and Gibbs, 1990), it also implicitly emphasizes the centrality of the category of traded goods in shaping legitimacy (see Suchman, 1995, for a review of the institutional and strategic views of legitimacy). The strategic view posits that markets are active social projects (White, 1981; Granovetter and Swedberg, 1992; Abolafia, 1997; Fligstein, 2002) and that participants' efforts can also define an institution's (here, a market's) moral legitimacy. Yet the efforts are still mostly depicted as deployed in service of the category of traded goods. As an example, when a good is deemed illegitimate for trade, participants can deploy narratives to try and legitimize commerce. The results of such efforts tend to be seen as applying to the market as a whole (Zelizer, 1979; Barley, 1983; Zelizer, 1985; Sanal, 2004). For instance, the entire life-insurance or funeral services market is shown to gradually gain legitimacy (Barley, 1983; Trompette, 2008; Chan, 2009a, 2009b). The category of traded goods remains a focal locus of legitimizing efforts and a key unit of scholarly attention.

These combined theoretical approaches leave variation in legitimacy for trades involving the same category of goods largely unexplained. In this article, I draw on an inductive qualitative study of participants in a contested market to show that how goods are traded also contributes to morality. Building on the literature on professions (Freidson, 1970; 
Hughes, 1971; Abbott, 1988), the study offers what I label a practice-based view of moral markets to help us better understand what makes markets moral. The practice-based view has the potential to explain, for instance, why some trades in babies or life might be deemed morally acceptable whereas other trades, also involving babies or life, might not, thus challenging the categorical approaches of much past literature on morals and markets. The context for the study is the commerce in human cadavers for medical education and research in the United States. Commerce is here understood in its historical definition, namely, as the exchange between human beings of products of nature (Zelizer, 2005: 293). The study relies primarily on archival trade data and on interviews with market participants, particularly the professionals facing a jurisdictional dispute in this commerce, to understand the pursuit of moral legitimacy.

\section{THEORIES OF MARKETS’ MORAL LEGITIMACY}

\section{The Institutional View of Moral Legitimacy}

Legitimacy is a central concept in the institutional literature. From its inception, the institutional literature has noted that legitimacy, not only efficiency, affects the survival of organizations (Meyer and Rowan, 1977). The concept of legitimacy and its associated survival-enhancing outcomes have since permeated much institutional scholarship (Deephouse and Suchman, 2008). Organizations are now seen as competing "not just for resources and customers, but for political power and institutional legitimacy, for social as well as economic fitness" (DiMaggio and Powell, 1983: 150). 
While legitimacy can come in various forms (Suchman, 1995), an important form of legitimacy entails moral legitimacy, which is how legitimacy is understood in the rest of this article. Moral legitimacy reflects a positive normative evaluation of an organization and its activities (Aldrich and Fiol, 1994). It is defined by what a community deems legitimate (Durkheim, 1973). As such, moral legitimacy reflects not whether an organization and its activity benefit the evaluator or fit his or her plausible cognitive frames but whether they are the "right thing to do" (Suchman, 1995: 579). Though the institutional literature has paid general attention to norms of appropriateness in markets (Tolbert and Zucker, 1983; Edelman, 1990; Dobbin et al., 1993; Lounsbury, 2001), it has not paid much attention to morality per se as a dimension of legitimacy. Nonetheless, a key insight from the institutional literature is that structural features are integral in shaping legitimacy (Meyer and Rowan, 1977; Scott, 1977; Zucker, 1986; Scott, 1992).

When applied to markets, this insight suggests paying careful attention to the category of traded goods. Many scholars studying morals and markets note similar normative inferences based on the categories of traded goods. Human life, death, and sexuality are typically seen as categories of goods deemed inappropriate for trade (Caprom and Radin, 1988; Anderson, 1995; Carruthers and Espeland, 1998). Human anatomical goods are also often considered taboo to trade (Titmuss, 1971; Scheper-Hughes, 2000; Delmonico et al., 2002; Satz, 2010). Such a taboo is implicitly meant to preserve a line between distinct social spheres (Fiske and Tetlock, 1997; McGraw and Tetlock, 2005). For instance, contract pregnancy is regularly denounced as undermining "the dignity of women" (Anderson, 1995: 168). As for the secondary market for life insurance, critics 
contend that it "violates the sanctity of life" (Quinn, 2008: 740). Comparing different entities or goods according to a common metric, in this case a market metric, tends to suggest that they belong to similar domains (Espeland and Stevens, 1998). And porosity between domains can put the entire category of traded goods at risk of commensuration. For example, a market in reproductive services can be seen as creating "adverse effects on all persons, not simply on those who choose to enter that market" (Caprom and Radin, 1988: 63). Similarly, for female prostitution, "the open market might render an understanding of women (and perhaps everyone) in terms of sexual dollar value impossible to avoid" (Radin, 1996: 133). In short, an institutional view of legitimacy strongly links a market's legitimacy to the category of traded goods.

Although the institutional approach does not discount the theoretical possibility of sources other than structural ones also defining legitimacy, it generally overlooks the potential for these sources (specifically participants' practices) to trump the categorical criterion. As an illustration, institutional scholars have noted how institutional entrepreneurs, through their repeated, often collective efforts can modify the ways institutions, industries, and markets operate (Johnson, 2008; Battilana, Leca and Boxenbaum, 2009; Kellogg, 2009). For instance, assumptions on what structural characteristics of labor markets for surgeons might entail can gradually shift, due to reformers' collective efforts (Kellogg, 2009). Participants' efforts are not deployed in vain and can help shape markets, including, hypothetically, their legitimacy. Such legitimizing efforts can take many forms, yet most institutional research has focused on participants' narratives (Hallett and Ventresca, 2006; Powell and Colyvas, 2008: 292 - 
295). Though participants' practices are also posited to sustain legitimacy (FourcadeGourinchas and Healy, 2007: 303-304), they have attracted less empirical attention. Thus in locating action mainly beyond the purview of individual market participants (Meyer and Rowan, 1977; DiMaggio and Powell, 1983; Dobbin et al., 1993), the institutional view still mostly emphasizes "the way in which market-wide structuration dynamics generate cultural pressures that transcend any single organization's purposive control" (Suchman, 1995: 572). In that sense, the category of traded goods "structures" a market's legitimacy more than individuals' efforts, particularly those deployed outside the narrative realm.

\section{The Strategic View of Moral Legitimacy}

The strategic view of legitimacy (Suchman, 1995: 575-576) seems initially to offer a very different answer to the question of what makes markets moral, but its research agenda also implicitly supports adopting a categorical approach through which to assess legitimacy. The strategic view posits that markets are active social projects (White, 1981; Granovetter and Swedberg, 1992; Abolafia, 1997; Fligstein, 2002) and that legitimacy can be constructed within markets (Fourcade-Gourinchas and Healy, 2007). This view can also be understood as a cultural approach to markets (see Mische 2011 for a discussion of culture and agency). Thus, market participants can make efforts to build or sustain a market's legitimacy by shaping, for instance, perceptions of their environment (Pfeffer and Salancik, 1974; Dowling and Pfeffer, 1975; Ashforth and Gibbs, 1990). More specifically, in many if not all markets, narrative devices are extensively used to construct markets and legitimacy (White, 1992, 2008; Kennedy, 2008). For example, 
grass-fed-meat-and-dairy market participants rely on narratives to promote their market (Weber, Heinze and deSoucey, 2008). In addition, participants' practices prove important in sustaining and legitimizing markets (Carroll and Swaminathan, 2000; Rao, Monin and Durand, 2003; Phillips and Owens, 2004; Hsu, 2006; Negro, Hannan and Rao, 2010). As an illustration, culinary practices, such as the way food is prepared, menus organized, and the chef"s tasks carried out figure preeminently in the definition of "nouvelle" cuisine (Rao, Monin and Durand, 2003). These findings help explain why the strategic approach has posited that alternate market features, generally linked to participants, can define an institution's (here, a market's) legitimacy (Suchman, 1995).

Despite the allowance for a broader range of sources of legitimacy, the strategic view depicts market participants' efforts as mainly deployed in service of the category of traded goods, thus implicitly acknowledging the category's centrality in legitimacy construction. This assumption is most evident in research on morals and markets. More specifically, diverse legitimizing narratives can be deployed to build the legitimacy of contested markets (Zelizer, 1979, 1985; Barley, 1983; Sanal, 2004; Quinn, 2008) but the results of these efforts tend to apply to the market as a whole. For instance, U.S. funeral home directors rely on narratives that depict the deceased as living individuals to legitimize their pursuit (Barley, 1983). The more convincingly they frame their tasks as caring for the living, the more legitimacy the entire market for funerals acquires. Likewise, in many other settings, such as the Chinese life-insurance market, the Danish pornographic film industry, and U.S. men's bathhouses, participants' efforts are seen as benefiting the entire market category (Jensen, 2010; Chan, 2009a, 2009b; Hudson and 
Okhuysen, 2009). More generally, the legitimacy of a market in given goods is depicted as waxing or waning as a whole, in accordance with participants' efforts. Put otherwise, a market's legitimacy level varies in lockstep with its goods' level of appropriateness to be traded. The market's assessment drives the goods' assessment, and vice versa. The strategic view again supports a categorical approach to legitimacy. These categorical approaches treat as anomalies "legitimate" markets in "improper" goods and "illegitimate" markets in "proper" goods. For example, the institutional and strategic views offer few conceptual tools to comprehend markets in sexual services that might be seen as legitimate. This study relies on the literature on professions to make sense of such anomalies.

\section{The Professional View of Moral Legitimacy}

All market participants engage to some degree in legitimizing efforts, but in contested markets closely associated with a professional group, professionals are particularly well positioned and motivated to make such efforts. Perhaps nobody struggles more with the question of morals than professionals in contested markets. Probably more than others, they have a vested interest in seeing their activities depicted as morally legitimate. Past research remarks that legitimizing efforts often appear to originate with professionals. In the life-insurance market, for instance, heads of trade associations have been shown to be instrumental in spearheading the adoption of narratives on protecting widows and orphans (Zelizer, 1979). Similar dynamics have been observed in the Chinese lifeinsurance market, in which life-insurance managers and sales agents have proven to be instrumental in developing a "money management" narrative legitimizing commerce 
(Chan, 2009a). Likewise, in the French funeral industry, directors of large funeral companies are vocal in claiming that they cater to each consumer's needs to justify the wide price range of their services and the legitimacy of the market as whole (Trompette, 2008). These findings suggest paying close attention to professionals' views of moral conduct in contested markets.

For participants belonging to a professional group closely associated with a given market, the question of a market's morality can easily become intertwined with the question of their professional jurisdiction. Professionals are often eager to shape the perceptions of legitimacy for their activities because their own jurisdiction is at stake (Freidson, 1970; Abbott, 1988). Their jurisdiction, or the "simple claim to control a certain kind of work" (Abbott, 1988: 64), is intertwined with how they and others view the work being performed. The work is tightly connected to their social identity (Hughes, 1971). For instance, challenging the morality of trading securities can easily be understood as challenging the morals of traders. Faced with jurisdictional disputes, professionals will use their power to retain their jurisdiction (Abbott, 1988: 134-142).

In the literature on professions, morality is inherently linked to how tasks are done, not to what goods those tasks involve. As an illustration, merely trading transistors and resistors does not make a person an electronic salesperson. Instead, the salesperson's ability to properly discount sale orders or provide clients with lunches, dinners, and golf outings is taken to indicate that certain individuals might rightfully belong to the profession, whereas others do not (Darr, 2006: 85-93). As such, work practices are inherent elements 
of defending professional jurisdictions (Abbott, 1988: 60-68). While inscribing professional claims into the legal arena provides an alternate way to uphold a jurisdiction (e.g., in certain states, only those individuals who succeeded at a bar examination are qualified to practice law), professionals rely as well on recurring practice-based distinctions to ensure the legitimacy of their pursuits. Practice-based distinctions include task distinctions, but also distinctions in how activities involving similar goods are performed (Van Maanen and Barley, 1984; Barley, 1986; Nelsen and Barley, 1997; Bechky, 2003; O'Mahony and Long Lingo, 2010). Such an ongoing practice-based distinction also upholds and shapes the legitimacy of the work performed. By focusing on the professionals traditionally associated with commerce in cadavers, this study aims to understand what makes the market and, within the market, their jurisdiction moral.

\section{SETTING AND METHODS}

\section{Commerce in Cadavers}

Historically, commerce in human cadavers was created by medical schools that trained future physicians. Most physicians undergo training in anatomy that requires the dissection of a cadaver. Finding an adequate supply of cadavers for this purpose often poses an ongoing challenge (Baumel, 1968; Dasgupta, 2004). The recent advent of anatomical training software does not seem to have dampened the demand for cadavers (Prentice, 2005). Other health-care fields, such as reconstructive dentistry and osteopathic medicine, also increasingly rely on cadavers or cadaver parts (jaws and joints, respectively) for initial training. And the continuing medical education of practicing professionals can often require cadavers or parts as well. For instance, medical device 
manufacturers regularly invite surgeons to training sessions in which they test new instruments on human remains (Gawande, 2002: 27). Overall, the demand for cadavers appears to be growing but is hard to estimate.

The supply of cadavers is slightly easier to assess. There is no federal monitoring of whole-body donation, but estimates suggest that the total number of U.S. whole-body donations approximated 20,000 in 2006 (Becker and Elías, 2007). The U.S. supply is controlled by close to 150 academically housed whole-body-donation programs (State Anatomical Board of Florida, 2006) and a dozen independent ventures, both for-profit and non-profit organizations. Academically housed programs are defined here as programs housed in facilities that focus primarily on higher education or research. By contrast, independent ventures are not affiliated with higher education or research institutions. ${ }^{1}$ Staff members of academically housed programs historically formed an "exclusive group of individuals applying somewhat abstract knowledge to particular cases" (here, whole-body donations) and therefore can be considered a profession (Abbott, 1988: 318).

Current U.S. legislation governing the commerce in cadavers constrains the purchase and sale of cadavers while facilitating their acquisition and transfer to meet medical demands (Madoff, 2010: 22-28). Since 1968, the Uniform Anatomical Gift Act (UAGA), adopted by every U.S. state, has provided a legal framework for such commerce (National Conference of Commissioners on Uniform State Laws, 1968). The act created a framework for obtaining donor's consent and prioritized the rights of next of kin to 
bequeath anatomical gifts of decedents who did not specify their wishes. A 1987 revision of the UAGA, enacted by most U.S. states, made it a felony to "knowingly, for valuable consideration, purchase or sell a [body] part for transplantation or therapy, if removal of the part is intended to occur after the death of the decedent" (National Conference of Commissioners on Uniform State Laws, 1987). To allow procurement programs to recover part of their costs, however, the 1987 act excluded "the reasonable payment [by users] for the removal, processing, disposal, preservation, quality control, storage, transportation, or implantation of a part." This provision allowed providers (in particular, independent ventures) to require "reasonable" payment for their services.

Though prohibitions on the purchase and sale of cadavers (as opposed to body parts), and for purposes other than transplant or therapy (such as education and research), were not spelled out in the act, its scope was usually interpreted as encompassing cadaver procurement, regardless of purpose. The 2006 revision of the UAGA made this loophole explicit by excluding the body in its entirety from the definition of a part: "The term [part] does not include the whole body" (National Conference of Commissioners on Uniform State Laws, 2006). As the California Supreme Court had previously clarified, "Given the current provisions of the Uniform Anatomical Gift Act (UAGA), there is no basis to conclude that there is a general public policy in this state prohibiting hospitals or medical centers from giving, or prohibiting patients from receiving, valuable consideration for body parts which are to be used for medical research or the advancement of medical science" (Moore v. Regents of University of California, 1990, 51 Cal. 3d 120; 271 Cal. Rptr. 146; 793 P.2d 479). Thus the purchase or sale of body parts 
or cadavers for purposes other than transplantation and therapy is legal as long as proper consent has been obtained. This legal framework has lent encouragement to the commerce in cadavers but has also given rise to a new jurisdictional dispute.

\section{Jurisdictional Dispute in Commerce in Cadavers}

Cadaver procurement in the United States operated historically mostly "outside of the legal process or in the shadows of law" and was commonly referred to as "bodysnatching" (Goodwin, 2006: 11). Those responsible for procuring corpses for medical schools often resorted to disinterring cadavers or paying others to do so (Sappol, 2002). Procuring cadavers generally proved to be illegal, was mostly deemed illegitimate, and hardly constituted a profession. In 1968, the UAGA's definition of the legal parameters for donations provided those involved in commerce in cadavers with a new legal basis for their pursuit. Though anatomical donations, like cadaveric organ transfers, mostly failed "to become routinized within the collective lay imagination" (Sharp, 2006: 41), they gained broader acceptance with the act's adoption. Gradually, leaders from major faiths also endorsed whole-body donations as acts in accordance with their respective traditions and, more importantly, as signs of generosity (Mitford, 1998). Inspired by such progress, academically housed staff members formed in 1991 a "Willed Body Directors" shared interest group at the American Association of Clinical Anatomists (AACA) (Cahill and Payer, 1991), as most academic programs were run (and still are) by clinical anatomists holding a Ph.D. in anatomical sciences, physiology, or physical anthropology. These changes provided new visibility and legitimacy for the profession. 
Starting in the 1980s, independent ventures, with names like Life Legacy and Science Care, took advantage of the opportunity offered by the legislation governing the commerce in cadavers to set up operations and source in the same geographies as academically housed programs. Gradually, the scale of their operations made them key players in commerce, prompting the Cato Institute to publish an article praising the commerce in cadavers as an example of an unregulated national market (Harrington and Sayre, 2006). By 2007, the two largest U.S. independent ventures were each securing several thousand donations per year as compared with a maximum of several hundred for the most successful academically housed programs. While academically housed programs received donations locally, independent ventures often reached beyond their home base. A study of a typical venture found, for instance, that the overwhelming majority of donations (82 percent) came from out of state (Anteby and Hyman, 2008: 965).

Professionals perceived the rise of independent ventures as a direct threat. Most ventures were run by individuals with no medical training, and professionals vehemently resisted early attempts by ventures' staff to join their gatherings. In a few states, local professionals even asked health officials to investigate the ventures' facilities to attest to their legality. Professionals also issued a policy statement noting their concern about "independent entrepreneurs, acting as third-party brokers" and "certain donor programs that appear to be operating for budget enhancement" (Cahill and Marks, 1991: 232). Like body-snatchers in the past, independent ventures' motives and character were depicted by professionals as distinct from those of academically housed programs (Associated Press, 2004; Davis, 2004; Lucas, 2006). Yet the difference between the academically housed 
programs' and the ventures' pursuits was not always apparent. As an illustration, a recent request for proposals for cadavers issued by the University of California System (required by the level of funding involved) was open to independent ventures and academic programs alike (Regents of the University of California, 2008). With their legitimacy only in its infancy, professionals were suddenly confronted with a jurisdictional dispute that echoed their worst fear, namely, being associated with the historical body-snatcher image (evoked by the new ventures) that their profession had tried hard to distance itself from.

\section{Research Design}

In this research, I used in-depth analysis of a contested market in a given geography to understand how markets are rendered moral from the participants' perspective. Any U.S. state might seem a suitable setting to study the commerce in cadavers, but few states keep extensive records of commerce. In 2007, however, the state of New York established an exhaustive legal reporting obligation (starting with the prior year) for "acquisition and use" of human cadavers. I therefore made a methodological choice to focus on that state and on the data from a given year, 2007. I chose the second year of obligatory reporting because data from the first year, 2006, included at least one reporting error, suggesting that some programs might need an initial year to perfect their reporting procedures, although analyses of the 2006 data support the 2007 findings reported here. The dynamics of New York's commerce in cadavers were typical in many ways of what could be found elsewhere. New York's legislature enacted a classic version of the UAGA, its medical schools have historically procured most donations, and a few independent 
ventures have been licensed to operate in the state. At the same time, professionals seemed more active and numerous in New York than in other states and were able to strongly limit independent ventures' in-state activities. In other states, such as Maryland and Minnesota, only a limited number of individuals seemed to have spearheaded efforts to legitimize commerce in cadavers. Thus New York represented a geography in which the efforts of professionals were likely to be more salient than in other settings.

\section{Data Sources}

I used three data sources to understand the efforts made by participants in the commerce in cadavers: archival data on the acquisition and use of cadavers in New York, interviews with market participants, and observations during program visits.

Archives. A state license is required to acquire and use cadavers in New York; fifty-three programs were licensed in 2007; Table 1 provides the details. All "nontransplant anatomic banks" licensed in New York to acquire and use whole bodies must submit activity reports to the New York State Department of Health. Failure to report such activities could lead to the loss of a license and consequent inability to operate in the state. "Non-transplant anatomic banks" are defined by New York State law as "any person or facility that solicits, retrieves, performs donor selection and/or testing, preserves, transports, allocates, distributes, acquires, processes, stores or arranges for the storage of non-transplant anatomic parts, including whole bodies, body segments, organs or tissues from living or deceased donors, for education and/or research purposes" (State 
of New York Public Health Law, 2007). Access to these reports was crucial in compiling a full picture of cadaver commerce in the state.

\section{[Insert Here Table 1]}

Interviews. To understand how the commerce in cadavers operated, a research assistant and I interviewed, respectively, 12 and 36 individuals; totaling 48 interviews. Table 2 provides details. The vast majority of the interviewees (38) were staff members at academically housed programs whom I label "professionals." The remaining interviewees were staff members of independent ventures and of the Office of the Chief Medical Examiner, as well as "industry" insiders, namely, two corporate users of cadavers (automotive-industry employees involved in crash-test research), two funeral directors often asked to transport cadavers, and an airline executive who specialized in the transportation of human remains. The interviews typically lasted 45 minutes and were conducted on site or by phone, often after face-to-face introductions at professional meetings attended by many staff members of academically housed programs. Interviews were organized around a consistent set of questions but were also tailored to respondents' areas of expertise and to the nature of their involvement in commerce. We asked all interviewees to provide examples of typical cadaver-acquisition-and-use decisions. Three-quarters of the interviews were recorded, and extensive notes were taken during all of them.

To form a sample of interviewees, we first contacted all individuals listed as contacts in the activity reports submitted to the New York State Department of Health. Of the 53 
individuals contacted, 28 agreed to be interviewed. Non-respondents did not appear to differ significantly from respondents with respect to program type or size. Though it is possible that programs refused interviews because they had failed to report their data accurately, the likelihood seems low: because I triangulated programs' replies, an entire set of "non-accurate" respondents would have had to decline interviews. Of the five independent ventures licensed in New York, the founders from three agreed to be interviewed. Another venture not licensed in New York also agreed to provide an interview. Most independent ventures appeared to operate on an identical model and were divided approximately equally between non-profit and for-profit organizations. To add robustness to the data, I also conducted interviews with out-of-state professionals selected via a two-step process. First, I approached randomly selected participants in sessions on anatomical donations at the principal annual meeting of clinical anatomists, explained my project, and inquired whether they might later agree to be interviewed; most respondents agreed. Second, I asked interviewees to suggest other potential interviewees. This process yielded a random sample of New York commerce participants and a snowball sample of participants in the commerce in cadavers nationwide.

[Insert Here Table 2]

Observations. I conducted on-site observations for a total of 15 days in six cadaver-procurement programs to familiarize myself with their operations. The sampling of observations was a convenience sample. All interviewees were asked at the end of the interviews whether they would permit day-long observations at their site. I observed both smaller and larger programs, as well as both academically housed and independent 
programs. I took extensive notes on the activities of staff members, ranging from program directors to administrative assistants. I also attended three consecutive annual conferences of the American Association of Clinical Anatomists (AACA), a professional association dedicated to advancing the art and science of clinical anatomy. At the AACA conferences, I attended and took extensive notes at the Anatomical Services Committee's session, which focuses on whole-body donations, and several presentations organized by that committee. Almost half of all U.S. academically housed programs participated in the committee's activities. Each of the three years that I attended, 50-100 participants came to the session. These sessions were the sole national annual venues for programs to exchange practices and ideas about the acquisition and use of cadavers.

\section{Data Analysis}

I began the analysis by reading and coding the interview data for ways in which interviewees described cadaver trades, in keeping with grounded theory guidelines (Glaser and Strauss, 1967; Miles and Huberman, 1994), including constant comparison. As an illustration, I treated any issues that participants repeatedly voiced in reference to cadaver trades as salient attributes of commerce. I gradually tracked the content of recurring themes, such as the legitimacy of trades, donors' consent, and the dissection of cadavers prior to use. As themes emerged, I returned to previously analyzed descriptions of trades to reexamine them according to the new themes. In parallel, I noted the interviewees' profiles alongside the ways trades were described. Identifying and comparing their contents across trade descriptions were iterative processes (GoldenBiddle, 2001: 45-62). To strengthen the analyses, an independent coder also read all the 
transcribed interviews to analyze recurring themes; we then compared themes, reread the interviews in light of each other's insights, and fine-tuned our shared understanding of the narratives. A second step in the analyses led me to examine actual patterns of cadaver trades in New York, paying close attention to the profiles of involved parties. I used archival data to reconstruct a map of commerce that identified the main cadaverprocurement and recipient programs and quantified flows of cadavers in the state. Finally, I also recorded observational data to identify key steps in the procurement and use of cadavers and to capture the nature of a typical day at a given program. In addition, annual-meeting field notes proved important for contextualizing some findings. Though many of these observations are not detailed here, they contributed substantially to my general knowledge of the commerce in cadavers.

\section{FINDINGS}

The findings detail how the professionals traditionally entrusted with commerce in cadavers handle the jurisdictional dispute. First, they rely on narrative distinctions to distinguish their own pursuit from an alternative sphere of commerce. Second, they geographically insulate their pursuit from an alternate one by trading a fair number of cadavers among themselves. A particular group of professionals - those I label "gatekeepers" - played a key role in maintaining such insularity. Yet besides narrating their work differently and trading select cadavers, the professionals, particularly gatekeepers, also promote proper ways of trading cadavers. The practice-based distinctions made by professionals between proper and improper commerce in similar goods suggest that how cadavers are traded is central to building legitimacy. 


\section{Distinguishing Spheres of Commerce via Narratives}

All interviewed professionals perceived themselves as operating within a "world" or "sphere" distinct from that of programs and individuals engaged in what they called "unethical" and "illegal" commerce. Characterization of the other sphere as immoral was widespread among academically housed respondents. As one professional put it, "for the most part willed-body programs are run on a pretty legitimate basis, [but] you are going to find a rascal in every business once and a while.” In New York in particular, all professionals drew a similar narrative distinction between spheres. ${ }^{2}$ The other programs were described as "outsiders" or as operating "off the radar." It did not matter that some "immoral" programs operated legally. Academically housed interviewees saw these programs as outsiders because they "duped naïve donors and their families about their motives." Operating off the radar suggested not only that the immoral sphere might engage in illegal practices but also that it might deceive potential donors and their families about its goals. While professionals saw themselves as pursing "higher goals," participants in the immoral sphere were said to engage in commerce "only for themselves." The perceived egotistic goals of independent ventures troubled the professionals and led them to condemn such ventures on moral grounds. In the eyes of academically housed interviewees, the independent entrepreneurs epitomized the immoral sphere.

Evidence of past misconduct was usually invoked in those instances to illustrate what was wrong with the immoral sphere. For example, "random occurrences that hit the press 
around the country of, you know, improper use of cadavers or body parts" were cited as proof of an immoral sphere's existence. What one interviewee called "the New Jersey example of stolen body parts"- an incident in which the bones of the television commentator Alistair Cook were stolen from a funeral home and sold for profit—was frequently mentioned as an example of how commerce could go wrong (for a description of the incident, see Scheper-Hughes, 2006). Similarly, independent ventures' marketing letters to funeral homes suggesting that families might "save money" if they agreed to "donate their loved one to science" were seen as evidence of wrongdoing. The funeral homes would be reimbursed for their transportation and cremation costs, and might therefore encourage families with limited means to consider this option. These letters reinforced the idea that ventures acted "only for themselves."

Whereas many independent ventures' interviewees downplayed the distinction between spheres and aspired to be perceived as an "equivalent option" to an academically housed donation, some also voiced pride in belonging to an alternate sphere. They questioned the morality of academically housed programs "turning down some cadavers that could be put to good use" and "not fully utilizing" the ones they accepted. The ventures' staff emphasized that their cadavers were "extensively" used and that multiple recipients benefited from the donation. Moreover, all independent venture interviewees considered the quality of services they provided to families and to specimen-users higher than those offered by academically housed programs. For instance, the ability to return cremated ashes to the family within months or to answer any users' needs on the spot was seen as 
evidence of superior service. Thus the academically housed programs lacked what the ventures saw as "organizational" skills.

Though generally described as distinct by professionals, the two spheres of commerce exhibited some porosity. For one thing, professionals acknowledged that problems they attributed to the other sphere could also arise in their own ranks. Several academically housed programs mentioned the "temptation to do things they should not be doing" when speaking about academic colleagues. As one professional pointed out, some recent scandals involving cadavers implicated staff members at academically housed programs (not independent ventures) who had sold specimens for profit. ${ }^{3}$ Furthermore, some professionals acknowledged the need filled by independent ventures. One such interviewee said that he occasionally referred families to these ventures when they inquired about donating a recently deceased relative he did not want to accept. He cited such ventures by name, without endorsing any of them, to "help the family" in "pursuing the path they had chosen." Despite the porosity, the narrative contrast between spheres was generally maintained. Overall, this contrast strengthened the distinction between the professionals' pursuit and an alternative course of action.

\section{Geographically Insulating Spheres of Commerce}

While professionals were establishing a narrative distinction between their activities and the broader market for cadavers, they were also actively engaging in commerce by trading a relatively high number of cadavers in New York. To avoid confusion in spheres and defend their jurisdiction, professionals located in New York opted to almost always 
trade only those cadavers secured in state by other academically housed programs. Such a strategy helped them trade cadavers while seeming to oppose market developments. Trades with out-of-state programs, particularly independent ventures, even those licensed in New York, were infrequent. Given how commerce in cadavers operates in the United States, these patterns point to purposeful trading practices. Archival data on cadaver acquisition in New York suggest that in-state programs essentially operated in a regional submarket. Of the 1,694 cadavers secured in 2007 by all non-transplant anatomical banks located in New York, only 31 (1.8 percent) came from outside the state. Moreover, these few out-of-state cadavers came from another academically housed program, not from independent ventures. Thus most cadavers acquired by in-state programs were procured locally and from academically housed programs, despite the availability of such specimens from out-of-state independent ventures. A similar insularity prevailed in specimen-usage patterns as well; in-state cadaver acquisitions were used exclusively within the state.

By contrast, independent ventures tended to acquire and send cadavers nationally, but none acquired whole-body donations in New York or sent cadavers to New York programs. Among the programs licensed in New York to acquire and use cadavers, five were independent ventures, all located out of state. These ventures actively recruited donors in many states, particularly those with high concentrations of retirees, like Arizona and Florida, but none reported donations in New York. Though it is possible that unlicensed ventures might be sourcing in state, ventures were typically quite careful to 
obey prevailing laws to counter the stigma often associated with their pursuits. Thus it seems unlikely that unlicensed independent ventures sourced in the state.

The existence of a regional New York submarket was facilitated by the active transfer between academically housed programs of cadavers, thus reducing the need for these programs to look to other sources, including out-of-state sources, for specimens. Table 3 provides an overview of the cadaver trades. In 2007, academically housed programs located in New York secured a total of 1,146 cadavers. Of these, 469 (41 percent) were transferred voluntarily to other academically housed programs. Though only a few programs had sufficiently ample supplies to distribute specimens, many programs benefited from their distribution. Nine in-state academically housed programs transferred cadavers they had acquired to other in-state recipients, and 70 percent ( 30 of the 43 ) of in-state academically housed programs received cadavers from another in-state program.

[Insert Here Table 3]

These transfers were voluntary and depended on programs' willingness to part with specimens they had acquired. Regardless of the number of donations, no academically housed program ever had "spare" cadavers. Cadavers could always be put to good usefor example, by lowering the number of students per cadaver in a class or by offering physicians advanced training in new procedures. Even so, some academically housed programs, the largest being referred to in state as "source" programs, voluntarily transferred cadavers to other programs, known as "recipients." Recipient schools were aware that such transfers depended on the willingness of source schools to part with their 
resources. As one recipient-school professional explained, "I am sort of in a position of a beggar." Source schools in turn reminded recipients that transfers were done at their discretion. The following quote is typical of the position of source programs: "I will be blunt: our school has no surplus. I do not supply all my [own] demands." Sources schools were transferring cadavers at a cost.

These cadaver transfers can be traced to the longstanding practice at some large programs of supplying smaller local institutions, which professionals at source schools called "community" or "affiliate" institutions. The term "affiliate" suggested a shared trajectory, but no formal connection linked the affiliate institutions and the programs that supplied them. For instance, a program housed in a large university regularly supplied two nearby community colleges with approximately five cadavers each per year. The community colleges, considered part of the "broader medical community" by the source program, trained nurse practitioners and physical therapists. Such local transfers were often referred to by the source schools as "social distributions."

These trade patterns created de facto a fairly insular commerce for cadavers in New York, thus achieving what most professionals hoped for, namely, the physical separation of their activities from those of independent ventures. In New York, transfers among programs ensured separate spheres on a fairly constant basis for specimens procured by academically housed programs and those procured by independent ventures. In other states, the goal of physical separation between spheres could be pursued mainly on a perprogram basis. For instance, as an out-of-state professional explained, "We do not allow 
our specimens to mix with other groups [of specimens].” In particular, he added, "I will not allow my specimens to be used with specimens from private brokers or for-profit ventures." This physical distinction was less clear cut in the commerce in body parts. Four of the independent ventures licensed to operate in New York sent parts to in-state users, mostly for specialized training and research needs, such as continuing orthopedicssurgery training and brain research. Despite some porosity between academically housed programs and independent ventures in the commerce for anatomical parts, the in-state commerce in cadavers remained fairly isolated from out-of-state trades, particularly trades with independent ventures. Such patterns of trade suggest an attempt to physically distinguish spheres of commerce within the broader commerce in cadavers.

\section{Professional Gatekeepers' Role in Promoting Select Trades}

The insularity of commerce in New York was largely traceable to the efforts of a select group of in-state professionals to supply their peers. Despite legitimate internal demand for cadavers within their host institutions, these professionals chose to distribute some of their specimens to other institutions. In particular, the four in-state academically housed programs that each secured annually more than 100 cadavers transferred 54 percent of their supply (460 out of 852 cadavers) to other academically housed programs. Five smaller in-state academically housed programs also distributed some of their acquired specimens. It is noteworthy that all nine schools supplying their academic peers were part of the Anatomical Committee of the Associated Medical Schools of New York (AMSNY). The decisions to coordinate efforts at the state level and to extend the transfer of cadavers geographically beyond the confines of affiliate programs originated within 
this professional committee. AMSNY is a consortium of public and private medical schools. Its anatomical committee was created in 1975 to improve whole-body donation practices. Membership in the committee was by invitation and grew gradually over the years from four members at its inception to 11 by 1979,15 by 1985 , and 18 since 1988 , as shown in Table 4. Over the past decade, the committee has promoted specimen transfers among its members by hosting yearly coordination meetings to discuss matching the supply of cadaver to the demand. By 2003, the committee had also started asking its members to voluntarily report annual cadaver transfers.

The subgroup of New York academically housed programs that belong to AMSNY's Anatomical Committee - those that I label "gatekeepers"-included only 18 of the 45 non-transplant anatomic-bank sites licensed for the acquisition and use of cadavers and located in New York. This group nonetheless accounted for 68 percent of all cadavers acquired in state $(1,146$ out of 1,694$)$ and for all cadavers voluntarily secured in state once the Chief Medical Examiner Office's numbers are excluded. Moreover, committee members were responsible for all in-state transfers of cadavers. Importantly, all gatekeepers were holders of doctorates, mainly in anatomical sciences, physiology, or physical anthropology. The gatekeepers tended to voice points of view on commerce expressed by many other professionals at the annual conferences I attended.

[Insert Here Table 4]

Gatekeepers played a central role in promoting proper sourcing. All but one gatekeeper mentioned this as a goal of the consortium. As a typical gatekeeper explained, "We 
wanted to make sure no school in New York State was forced to go to unethical sources to get cadavers." As another gatekeeper noted, "If we cannot supply the needs of all our members, we will force some to go outside and look for cadavers." The existence of "less honorable" outsiders was perhaps best captured by a professional at a recipient school, who recalled his initial interactions with gatekeepers. In his words, "they wanted to get everybody, all of the schools in the state who either accept donations or use cadavers ... to come together in that sort of blanket organization" and to make sure "that everything was done legitimately and above-board." He explained the gatekeepers' efforts as relating to concerns over "the way some of the things were being handled by certain less-thanwell, what am I trying to say? - less-than-honorable, I guess would be the best way to put it, persons at the time.” The honor or legitimacy of commerce was at stake.

Gatekeepers were particularly concerned over the years about the need to regulate the commerce in cadavers. Yet freedom of interstate commerce prevented even receptive legislators from barring out-of-state ventures from operating in the state. Legislators did require ventures to register as licensed "non-transplant anatomic banks," however, and most of the largest national ventures complied. Even so, gatekeepers were often disappointed by the lack of more stringent legislation. "The people who sell you houses are regulated," explained one gatekeeper. "The people who make food for you are regulated. . yet something as big and as important as body donations are not!" Concerned academically housed programs therefore took it on themselves to shape commerce via a group of like-minded peers. 
The gatekeepers' concerns were also partly self-serving. They mentioned their fears that unethical conduct would have a ripple effect on potential donors' willingness to register, and ultimately on the supply of cadavers. They also invoked the need to maintain "public trust" and the likelihood that "public impression would probably govern the availability of bodies far more than any regulations would." Scandals involving cadavers could have "an impact on all of us," one gatekeeper noted, because potential donors would be "far less likely to actually go through with a donation if they think something illicit may be done." Another gatekeeper pointed out that it would be to his own "benefit that there be no scandals involving anatomical materials at medical schools in New York State." He added, if someone acts unethically "that could come back and bite," and clarified, "So while, yes, you could say that it [transferring cadavers] was a good thing to do, it was also the right thing to do for our own programs." Gatekeepers wanted, in effect, to protect their own sphere.

\section{Distinguishing Spheres of Commerce via Practices of Trade}

In addition to employing distinct narratives to describe the two spheres and maintaining a physical separation between spheres, gatekeepers also developed a set of practices for trading cadavers to defend their jurisdiction. The practices went beyond mere compliance with prevailing law. As one gatekeeper put it, certain practices might "strictly speaking, be legal, but that does not make them ethical." These practices suggest how to trade cadavers properly and, by implication, how not to do so. Many trading practices, such as that of "never removing fingernail polish from a cadaver so medical students remember this cadaver is somebody," were mentioned in interviews. Those mentioned by more than 
half the interviewed professionals are explained below and summarized in table 5. All programs run by professionals followed the "proper" practices described below for setting specimen users' fees and prioritizing users' needs, but these programs did not consistently follow practices relating to donor's consent and the dissection of specimens. The fact that some programs did not enforce all practices did not undermine the collective pursuit; a full consensus, though desirable, was not needed to uphold their overall goals.

[Insert Here Table 5]

Covering costs versus making a profit. Payment for services needed to secure specimens was an accepted practice among all interviewees working in academically housed programs or ventures. In line with the 1987 Uniform Anatomical Gift Act guidelines, the "reasonable payment" by users to cover specific costs linked to procurement of a cadaver, such as transportation and embalming costs, could be invoiced by the source to the recipient program. Similar wording was included in the act's 2006 revision. In New York these costs amounted to approximately $\$ 1,500$ per in-state transferred cadaver. There was little variation in cost between one academically housed source program and another, and costs were stable over time. As one typical gatekeeper explained, "We sat down and figured out all the expenses we have wrapped in this- the labor, the supplies, and the time factor involved. And we just got it [the cost] that way."

Charging procurement fees in excess of actual costs, though legal, was largely condemned at academically housed programs. Most professionals, particularly gatekeepers, viewed even modest profits with concern. Some believed that prevailing law 
banned any profit. "I am not allowed to make a profit," one respondent explained. "All we do here is pass on the costs. I need to pay people who do the work for me. That's it." Most professionals, though aware of legal tolerance of some levels of profit, nevertheless considered pursuing profit to be unacceptable. "Programs in it for the money are a corrupting influence and need to be closed down," one interviewee declared. Another speculated, "I could probably, if I wanted to, easily demonstrate that, you know, someone should be reimbursing us $\$ 2,000$ a cadaver if I wanted to build that profit in, right? . . That's not happening as long as I have something to say about it." This stance was widely shared among professionals. "Some people do it for money," another typical advocate of closing profit-driven programs noted, "but many folks do not understand that money will be made on grandma." Only covering procurement costs was deemed appropriate.

A desire to expose what they called the "deceit" of some independent ventures also informed the gatekeepers' practices. In particular, the ventures registered as non-profit organizations, it was noted, still made profits; "they only reinvest them in the venture." The following quote captures this stance: "There are many non-profit companies that manipulate perceptions. Their non-profit status has nothing to do with the work of God [or charitable work]. Many people are misled by this non-profit term." Overall, professionals distinguished between their own programs and ventures by noting that the former made no profit. The habit of earning "legally accepted levels" of profits was not considered an option by gatekeepers or by the vast majority of professionals. 
Obtaining donors' versus families' consent. In all U.S. states, including New York, a cadaver can legally be donated, after death, without the deceased's explicit prior consent. Such legislation is meant to generate a sufficient supply of cadavers for the needs of medical education and research. All states permit donations by immediate next of kin (spouses, parents, adult siblings, and adult children). In all but one state, the law also allows for donations by guardians; in half the states, individuals unrelated to the deceased, such as a public-health officer or a chief medical examiner - those likely to handle unclaimed cadavers - can consent to donation.

Though acquisition of unclaimed cadavers and those donated by family members was legal in most states, few interviewed professionals relied on this acquisition channel. Local legislation in only a few small geographic regions of New York barred such acquisitions. Yet cadavers acquired this way in all other geographies were generally deemed inappropriate; the vast majority of academically housed programs required prior direct consent of the deceased. ${ }^{4}$ As one gatekeeper explained, "First of all, we require the individual to be signed up themselves [in other words, not by others] prior to death." Such programs maintained lists of registered donors to ensure that "proper" consent had been obtained and donors were also asked to discuss their wishes with family members. In most instances, potential donors had submitted consent forms years before death to ensure that their wishes to donate their body to science would be followed. As further evidence of discomfort with family donations, the rare professionals that relied in part on family donations often exhibited a need to justify their practices. For instance, a professional who obtained approximately 70 percent of his specimens via individual 
consent but complemented that supply with family donations minimized the stigma attached to the practice. In his words, the latter donors "might have talked about it with family members, but they just never signed the forms," thus allowing him to partly normalize his actions.

By contrast, the professionals noted that independent ventures were in the habit of approaching families, rather than donors, in their efforts to obtain consent. Interviews with ventures partially confirmed that perception: approaching family members was the preferred way to secure donations in the initial years of operations. "In our first few years," one venture staff member noted, " 80 percent of specimens came via family, not donor, consent." With time, however, the same ventures began compiling their own lists of potential donors and increasingly obtained consent from the future donor, not his or her family. This gradual shift did not prevent ventures from still approaching relatives of potential donors, particularly the gravely ill, to explain the process of "donating a body to science.” Independent ventures typically employed "development" staff conducting outreach efforts to hospitals' and hospices' populations, including chaplains, to help locate potentially amenable donors or relatives.

Professionals' views on what constitutes proper consent (i.e., direct donor consent) were also embodied in their practice of generally not engaging in commerce with the Office of the Chief Medical Examiner. In 2007, for instance, the office offered 548 cadavers to academically housed programs in all five Manhattan boroughs. ${ }^{5}$ These cadavers had always been identified by family members, but not claimed; they were therefore 
technically unclaimed, though not anonymous, and were therefore akin to donations with families' consent. Despite the office's practice of only releasing identified cadavers to academically housed programs, only 74 such cadavers were accepted by four academically housed programs (including members of the AMSNY's Anatomical Committee). Another 175 went to an embalming school, and the remaining 299 went unused. The condition of specimens was occasionally cited as a reason to reject unclaimed cadavers, but this was not the sole reason for the professionals' reluctance to accept them. A rare professional who accepted such specimens noted that the specimens were often useable. "I always tell my colleagues that they need to go there to find specimens, but I do not understand why they don't. I often am the only one responding to a call by the chief medical examiner. All of them should be running there to find specimens." Instead, most professionals, though they needed cadavers and were located near one of the office's five sites, relied on more distant academically housed programs to fill their needs.

Most professionals expressed normative reluctance to use unclaimed cadavers, as exemplified by the following typical comment from one professional not working with the morgue. In the past, he explained, the organization that was supplying him with cadavers "occasionally got the cadavers from unclaimed bodies, I think in the New York City area." Though he knew the practice was legal, "that's a little less respectable because those people didn't make a donation. Those people died as transients and then subsequently their bodies were given away, so to speak, by the city morgue." In his 
words, this was an improper "means" of acquiring cadavers. Only direct donor consent was the "honorable" way to operate.

Prioritizing versus answering needs. All three versions of the Uniform Anatomical Gift Act $(1968,1987,2006)$ have specified the intended use of anatomical specimens, namely, for transplantation or therapy. Though the acts regulate use of anatomical specimens for these purposes only, they have been widely regarded as applying to other intents as well. In particular, all of the programs (including ventures) that used specimens for medical education and research viewed themselves as operating under the UAGA rules. But not all medical education and research intents were deemed equally worthy by interviewed professionals who made it a habit of screening cadaver requests for intent. The gatekeepers articulated a particularly narrow hierarchy of acceptable uses, with the development of the medical profession as a priority.

The highest priority for gatekeepers was basic anatomical teaching needs, mainly the training of first- and second-year medical students. One staff member of a large source program explained that while colleagues "cannot teach their introductory gross anatomy course...I am not going to send cadavers to any institutions for a post-graduate training course, a research program, continuous medical education or anything like that. That is not going to happen." The needs of other physicians-in-training were a secondary priority. Residents in surgery, emergency medical training, ob-gyn, and the like were also considered priority recipients. Next in line were allied health professionals, such as physical-therapy students and physician assistants, but only once the needs of medical 
students had been filled, because there were not "enough specimens to go around." In addition, undergraduate courses were sometimes deemed acceptable recipients, but some professionals imposed more restrictions on such uses. The rule that "only people going for a state-licensure-affiliated health degree can touch a cadaver" often applied.

The more contested intended use of cadavers in medical education was in "clinical courses" and ad-hoc continuing-medical-education seminars. The latter category often proved somewhat variable in content. For instance, it included both short training programs aimed at certifying practicing physicians and training in the use of companyspecific medical devices, although the former were deemed more appropriate than the latter. The reasoning behind such contestation was articulated by a typical gatekeeper while describing the latter use: "We do not deal with private companies like Johnson \& Johnson. But if a physician in our medical school sponsors a class and J\&J foots the bill, then we are OK. As long as our faculty members are the ones requesting specimens, we trust them to advance medical education and research." The "big companies" were left to acquire "lots of their materials" from the independent ventures, with often less stringent criteria for intended use. ${ }^{6}$

Finally, most professionals were united in their condemnation of the "traveling body exhibit," an atypical but highly visible use of cadavers. "This is the worst," one interviewee explained. "Putting bodies into traveling exhibits is just wrong. It's all for show and play, something for the Middle Ages." Though a few representatives of academically housed programs saw "some educational purpose" in these exhibits, they 
were repeatedly compared unfavorably with the medical education and research pursued in their programs. No professional stated that she would allow her specimens to be used in such a manner.

Respecting versus processing a cadaver. The question of a cadaver's integrity arose at two specific junctures in commerce: at the outset, in the case of preparing acquired specimens, and often post-use, when cremating remains. No state law or legal ruling specified that cadavers needed to be kept whole. In fact, legislators had never addressed this practical issue. Post-use cremation practices elicited broad agreement among professionals, but interpretations of proper conduct varied with respect to initial preparation of the specimens.

Post-use cremation practices among professionals were mainly guided by the desire to preserve the integrity of remains. They expended much effort to ensure that used cadavers (and occasionally parts) were returned to the source program for cremation, and gatekeepers asked their staff to report the number of cadavers returned each year to source programs. Even so, the threshold of integrity could at times be open to debate. For instance, temporal bones were occasionally deemed integral to the body and sometimes not. One professional "asked them back from users, so we can cremate them with the rest." Another program "usually let the specimen users dispose [of] them. . . Since nothing is left but bone dust, we consider this disposable material.” Despite such definitional variation, most professionals aimed to preserve the integrity of cadavers when cremating remains. Some independent ventures also adhered to the same practice. 
By contrast, with regard to a cadaver's integrity prior to use, the two spheres of commerce differed starkly. All interviewed staff members of ventures noted that dissection prior to use was the norm in their operations. The vast majority of interviewed professionals opposed dissection of cadavers prior to use and provided normative reasons for their position. The comment that "cutting bodies up and distributing parts is not what we are about" captured these respondents' position. As one professional put it, "Some programs say the body will be segmented. Let's be clear: that means processed! They basically remove all but the head and the hands. . . I worry about that." Another professional clarified, "we are not in the business of distributing partial remains." A third added, "There are places that want just a certain part of the body, and I don't feel very comfortable cutting the body up and sending it all over the place. ... I would rather not cut the body up [and] respect a cadaver." For professionals, preserving a cadaver's integrity prior to use was seen as a form of respect, although practical considerations also occasionally guided some professionals' views. For instance, two professionals cited the potential difficulty of tracking body parts.

Even though most professionals did not dissect cadavers prior to use - a practice also shared by the majority of gatekeepers, a few professionals at large programs, particularly in source programs in New York, endorsed the practice. They believed strongly in maximizing specimen use by sending parts, not just whole cadavers, to users. The same interviewees usually also encouraged re-use of specimens and parts when possible. In particular, when a donor proved unsuitable for an anatomy course (e.g., due to obesity), 
dissection prior to use was deemed appropriate. "If a donor is not suitable, then I harvest from the cadaver and get specific parts, such as arms, legs, et cetera," one interviewee explained. "You can find seventy different purposes for each of these parts."

\section{DISCUSSION}

The legitimizing efforts deployed by professionals and independent ventures' staff in securing cadavers constituted an interaction order in which alternate meanings of commerce were at stake. From a traditional acceptation involving mainly local sourcing and a fairly esoteric professional knowledge, the U.S. commerce in cadavers evolved to become an entrepreneurial pursuit spanning the entire country and requiring organizational rather than professional expertise. Moreover, independent ventures achieved a partial "commodification" of the traditional professional activities linked to securing cadavers by transforming these activities into commodities, which could then be bought and sold without the involvement of jurisdictional professions (Abbott, 1988:

146). Staff members of academically housed programs, mostly trained medical professionals with a Ph.D., were suddenly confronted with an alternate view of their activities - a view that relied on new ways of upholding expertise (i.e., organization and commodification) directly competing with the older professional system (Abbott, 1988: 324).

The contest over the meaning, and ultimately the legitimacy of commerce, was not being waged through legitimizing all cadaver trades, but in practices undertaken at the bottom of consent forms, in programs' profit-and-loss balance sheets, in priority cues of 
specimen-users' demands, and on dissection tables upon receipt of cadavers. The struggle between legitimate and illegitimate commerce and its associated jurisdictional dispute were about practices of trade involving "similar" goods. The issue was not whether cadavers (as a category of goods) or only a subset of cadavers (New York specimens) could be traded, but how cadavers should be traded in order for commerce to occur. The "character" of the profession (Abbott, 1988: 190) was seen in essence as intertwined with the ways trading activities were performed. Whether potential donors and their families were persuaded by the professionals' character remains to be seen, but professionals were able to develop among themselves a relatively shared understanding of morals.

In keeping with the importance of classification and distinction in sustaining morality (Durkheim and Mauss, 1903; Needham, 1973; Douglas, 1986, 2002), the professionals promoted a view of commerce requiring several "tests" (Boltanski and Thévenot, 1999, 2006) that had to be met in practice to render commerce legitimate. First, accepting only specimens originating in-state and from other academically housed programs suggested legitimacy, but origin was not a sufficient criterion for legitimacy. Obtaining a donor's direct consent, asking for reimbursement of only the procurement costs, prioritizing users' needs, and refusing to dissect a cadaver prior to use formed a set of practices more strongly pointing toward moral legitimacy. The narrative framing of trades did not suffice to shape morals. Instead, practices of trade helped professionals specify and defend their jurisdiction and the legitimacy of their pursuit. 
By contrast, the independent ventures championed a view of commerce that centered on catering to specimen-users' needs and on the belief of engaging in an extensive use of cadavers, in essence, creating contest and dissonance among market participants (Kaplan, 2008; Stark, 2009). Such a view justified securing, if needed, donations from family members (not donors) and dissecting cadavers prior to use to allow as many users as possible to benefit from cadavers. Reasonable profits (above and beyond costs) were seen as normal means to achieve these ends. In that spirit, the ventures' staff viewed the professionals' unwillingness to answers all users' demands (via priority cues) more as evidence of their limited organizational capability than of the legitimacy of their endeavor.

Because some professionals in New York, those that I labeled gatekeepers, were able to institutionalize their perspective on commerce via the control and coordinated distribution of "proper" specimens to other academically housed programs, their perspective was fairly consistently enforced. By accepting the "social distribution" of specimens, other professionals implicitly accepted the social contract attached to them, namely, following proper practices of trade. While lower sourcing costs might have also influenced the recipient programs' decisions, the aspiration to belong to a legitimate sphere of commerce was probably as central, if not more so, to their decisions.

\section{Contribution to the Institutional Literature}

This study's findings challenge a central assumption of the institutional view on morals and markets by shifting the focus of moral assessment away from the good itself toward 
the practice of trade. The institutional view supports the moral stance as reluctance to trade certain categories of goods (Caprom and Radin, 1988; Anderson, 1995; Carruthers and Espeland, 1998). This study shows that how trades are conducted can also render markets moral and explains the "anomalous" occurrences of legitimate markets in improper goods. As such, the study answers calls to examine how "contested constructions of normative models" guide the institutional organizing process (Scott, 2001: 118) and explores the "workings of various sources of legitimacy" (Deephouse and Suchman, 2008: 68), thus providing insight into the micro-foundations of institutions (Powell and Colyvas, 2008) and how institutions are inhabited (Hallett and Ventresca, 2006). Though the categorical criterion remains a useful shortcut for moral guidance, this study suggests that a taboo on trading certain goods may be an excessively conservative device to guard against immoral markets. A ban on all trades in improper goods might prevent some properly executed trades from being conducted. Assuming that proper practices of trade can be enforced, the focus on categories of goods might give way to a more practice-based view of moral markets - one relying on practices of trade to guide moral action — at least for market participants.

The view of grounding legitimacy in practices echoes the position of pragmatic philosophers, such as Charles S. Peirce and John Dewey, that individuals solve problems by relying on practical habits that include "coherent repertoires" for acting vis-à-vis a set of given problems (Gross, 2009: 371). Other scholars have also repeatedly noted that the collective enactment of practices over time can produce and reproduce social order and meanings (Ortner, 1984; de Certeau, 1988; Bourdieu, 1990; Knorr-Cetina, 1999; Swidler, 
2001). In given markets, communities of practices can, for instance, pave the way for guiding social action and for moral legitimacy to emerge (Lave, 1988; Lave and Wenger, 1991; Orr, 1996). The practice-based view of moral markets builds on these literatures, alongside those on professions, by calling for close attention to participants' practical responses to given market situations involving the same category of goods as ways to gain legitimacy.

An implication of such a practice-based view of moral markets is that markets traditionally seen as uniformly moral or immoral can include spheres or sub markets, each with its own morality, that are distinguished along lines of practices. Thus the question of whether any given market is moral might be misguided. The question can only apply to sub markets. This also implies that markets in goods that are usually deemed legitimate to trade can lose their moral legitimacy when such trades are conducted improperly. This point is well illustrated by the recent U.S. crisis involving home mortgages. Some data suggest that loan-generation practices were increasingly out of keeping with loan officers' longstanding norms (de Michelis, 2009: 6). Further research might focus on common practice-based distinctions in spheres across markets to identify potential classes of practices that point toward the construction of legitimacy. Typical classes of practices might, for instance, entail ones upholding distinct participants' rights (e.g., donors' vs. specimen users' or borrowers' vs. lenders') or favoring varying scopes of beneficiaries (e.g., society vs. individual entrepreneurs or nations vs. financial institutions). Research designs across markets and spheres would allow for clearer cataloging and a better understanding of classes of "moral" practices. 


\section{Contribution to the Strategic Literature}

The literature adopting a strategic view on legitimacy also partly fails to distinguish or explain variations in levels of moral legitimacy in different trades involving the same category of goods (Zelizer, 1979, 1985; Barley, 1983 Sanal, 2004; Quinn, 2008; Chan, 2009a, 2009b). This study suggests that participants' legitimizing efforts can be directed toward only select trades. We already know that a given market can harbor distinct "circuits of commerce" (Zelizer, 2005) in which goods that appear to be similar can take on very different cultural meanings and that those meanings can vary depending on forms of payment as well as the recipients of pay (Zelizer, 1985: 169-207). But those circuits can also entail contrasted morals: in that sense, circuits for "fair" vs. "unfair" blood or "ethical" vs. "unethical" organs can coexist. Although past research on markets has focused on their subdivisions (Carroll and Swaminathan, 2000; Rao, Monin and Durand, 2003; Phillips and Owens, 2004; Hsu, 2006; Weber, Heinze and deSoucey, 2008; Negro, Hannan and Rao, 2010), it has largely steered clear of considering moral subdivisions or discussed moral branding within a market. For example, not all trades in mortgagebacked securities might be morally equivalent. Further studies might identify the conditions under which such moral categorization emerges. The absence of a central authority enforcing an agreement among participants and participants' lack of prior social ties have been posited to encourage the emergence of (moral) categorization (Zelizer, 2010: 307). A market's audiences might be an added dimension to consider when examining such emergence and the shaping of the moral debates. As an example, markets with small, peer-based audiences might prove more amenable to moral distinctions. By 
contrast, markets with large, diverse audiences might lend themselves less to such distinctions.

This study also contributes to the strategic literature by highlighting the role of practice avoidance in sustaining legitimacy. The strategic literature recognizes the importance of practice adoption in shaping legitimacy (Carroll and Swaminathan, 2000; Rao, Monin and Durand, 2003; Phillips and Owens, 2004; Hsu, 2006; Kennedy and Fiss, 2009; Negro, Hannan and Rao, 2010), but has less explored the role of systematic practice avoidance in this same construction (e.g., avoiding dissecting a cadaver prior to use). Distinctions are seen as providing the basic building blocks of social life and sustaining salient boundaries that help, in turn, to define communities (Lamont, 1992, 2000; Lamont and Molnár, 2002; Rao, Monin and Durand, 2005). As Douglas (2002: 5) noted, ideas about separating or demarcating impose "system on an inherently untidy experience." By extension, the absence of strong distinctions is said to lead to a crisis of identity (Douglas, 1986: 96). This implies that the ability to identify impurity is inherent to the moral pursuit: knowing how not to trade is as important as knowing how to trade. The harvesting of genetic material illustrates this point well. Refraining from reimbursing consequent travel costs (e.g., plane tickets) to individuals who have agreed to provide genetic material is deemed proper practice, and individuals expect only a "token" recognition of inconvenience (Ertman, 2009: 1033). It is not only what is done but also what is not done (here, not paying for consequent travel costs) that sustains legitimacy. Further research might identify practices that are systematically avoided across markets to document and explain common limits to markets. 


\section{Contribution to the Literature on Professions}

Another contribution of this study is to highlight the role of morals as legitimizing devices for professions. In the twentieth century, "character [i.e., morals] lost much ground" as the basis for legitimizing professional work domains (Abbott, 1988: 191).

With the recent rise of contested markets in such diverse domains as agriculture, finance, and medicine, professional character might regain some of its lost ground (see Khurana, 2007, for such a discussion). Professions clearly do not epitomize morality, and they "seize all sorts of human activities, not just the moral ones" (Abbott, 1988: 324). Professions nonetheless tend to enforce some sense of order on activities (Durkheim, 1964; Freidson, 1994). The gradual inclusion in commerce of goods previously deemed off limits to trade might therefore offer new opportunities for professions to test their ordering capacity. In such instances, professional boundary work involving moral claims will almost certainly intensify (Gieryn, 1983, 1999). Though character has historically grounded many professions, its role in sustaining contemporary professional legitimacy remains to be more fully explored. As an illustration, the recent development in the United States of paid emergency medical technicians (EMTs) alongside traditional volunteer EMTs offers a window into how morals can justify professional pursuits (Nelsen and Barley, 1997). While volunteer EMTs viewed themselves as altruists drawn from the local community, paid EMTs gradually positioned themselves as public servants able to systematically rise above the sensationalism of the task and assist all patients, not just the ones involved in the most traumatic events. Volunteer EMTs were depicted as "trauma junkies" and paid EMTs as the ones dedicated to a larger social good (Nelsen 
and Barley, 1997: 7). In the process, paid EMTs were able to claim higher moral ground than the volunteers. Future research might want to shed light on the conditions (besides jurisdictional disputes) under which professional morals might gain saliency.

This study also suggests considering more broadly the layered foundations of professional "character" or morals. Morals are often presented as one form of jurisdictional settlement (Abbott, 1988: 69-79). When considering jurisdictional settlements, character is also seen as competing with other legitimizing strategies, such as technical legitimacy (Abbott, 1988: 191), but such a view misses the tight interplay between morals and practices (or techniques). Studies on the conduct of British naval officers and North American zookeepers both exemplify such an interplay. During the sixteenth and seventeenth centuries, British naval officers were socialized into being “gentlemen" by learning how to intercept foreign ships (Elias, 2007: 30-31). The proper steps they followed for interceptions sustained and reflected their character. Likewise, North American zookeepers' current embrace of practices aimed at breeding captive animals are tightly aligned with their moral duty to protect endangered species (Bunderson and Thompson, 2009: 40). Future research might consider examining the interplay between character and other legitimizing strategies across multiple settings. Mutual reinforcement, rather than competition, between legitimizing strategies within a profession might be the norm. In addition, research designs distinguishing between profession-specific bases of morals and broader cultural bases of morals would advance our understanding of the foundations of morals. As an example, the perceived legitimacy of commerce in kidneys has been shown to be partly associated with trust or distrust of 
markets more generally (Leider and Roth, 2010). Likewise, the legitimacy of commerce in cadavers might have benefited from a growing legitimacy of markets more generally in contemporary society. Closer attention therefore needs to be paid to the internal as well as the external foundations of character in professions.

Given the preeminence of markets in society (Hirschman, 1982; Fourcade-Gourinchas and Healy, 2007; Sandel, 2009) and assuming that markets "construct society" (Fourcade, 2007: 1019), it is crucial to better understand how markets are rendered morally legitimate. Though the commerce in cadavers is an extreme setting in which to study markets, the relationship between practices of trade and professions and morality is likely to apply to other markets as well, such as "fair" trade or "ethical" investing. Practices of trade can be thought of as the products of long, chaotic chains of decisions. At the same time, practices are frequently rooted in professional conduct and constitute an integral facet of the market and its morals. Although the category of traded goods is generally considered when assessing a market's moral legitimacy, it only constitutes a starting point. A market's legitimacy is also defined by how trades are conducted. In a practicebased view of moral markets, legitimate trades in improper goods and illegitimate trades in proper goods are not aberrations. Instead, they are at the forefront of contestation over meanings of commerce - a front that is likely to grow with the spread of markets in our society. 


\title{
REFERENCES
}

Abbott, A.

1988 The System of Professions: An Essay on the Division of Expert Labor. Chicago: University of Chicago Press.

\author{
Abolafia, M. \\ 1997 Making Markets: Opportunism and Restraint in Wall Street. Cambridge, MA: \\ Harvard University Press.
}

\begin{abstract}
Aldrich, H. C., and C. M. Fiol
1994 "Fools rush in? The institutional context of industry creation." Academy of Management Review, 19: 645-670.
\end{abstract}

\begin{abstract}
Almeling, R.
2007 "Selling genes, selling gender: Egg agencies, sperm banks, and the medical market in genetic material." American Sociological Review, 72: 319-340.
\end{abstract}

\section{Anderson, E. S.}

1995 Value in Ethics and Economics. Cambridge, MA: Harvard University Press.

\section{Anteby, M., and M. Hyman}

2008 "Entrepreneurial ventures and whole-body donations: A regional perspective from the United States." Social Science and Medicine, 66: 963-969.

\section{Ashforth, B. E., and B. W. Gibbs}

1990 "The double-edge of organizational legitimation." Organization Science, 1: 177194.

\section{Associated Press}

2004 "UNE program bars for-profit sales of cadavers." Associated Press Newswires. March 17. 


\section{Barley, S. R.}

1983 "Semiotics and the study of occupational and organizational cultures."

Administrative Science Quarterly, 28: 393-413.

1986 "Technology as an occasion for structuring: Evidence from observation of CT scanners and the social order of radiology departments." Administrative Science Quarterly, 31: 78-108.

\section{Battilana, J., B. Leca, and E. Boxenbaum}

2009 "How actors change institutions: Towards a theory of institutional entrepreneurship." Academy of Management Annals, 3: 65-107.

\section{Baumel, J. J.}

1968 "Donation of bodies for medical education." Nebraska State Medical Journal, 53: 90-92.

\section{Bechky, B.}

2003 "Object lessons: Workplace artifacts as representations of occupational jurisdiction." American Journal of Sociology, 109: 720-752.

\section{Becker, G. S., and J. J. Elías}

2007 "Introducing incentives in the market for live and cadaveric organ donations." Journal of Economic Perspectives, 21: 3-24.

\section{Boltanski, L., and L. Thévenot}

1999 "The sociology of critical capacity." European Journal of Social Theory, 2: 329377.

2006 On Justification: Economies of Worth. Princeton, NJ: Princeton University Press.

\section{Bourdieu, P.}

1990 The Logic of Practice. Stanford, CA: Stanford University Press. 


\section{Bunderson, J. S., and J. A. Thompson}

2009 "The call of the wild: Zookeepers, callings, and the double-edged sword of deeply meaningful work." Administrative Science Quarterly, 54: 32-57.

\section{Cahill, D., and A. Payer}

1991 "Session on current issues concerning the Donor Management Program in the Proceedings of the American Association of Anatomists Annual Meeting." Anatomical Record, 231: A4.

\section{Cahill, D. R., and S. C. J. Marks}

1991 "Memorandum adopted by the American Association of Clinical Anatomists May 31, 1990." Clinical Anatomy, 4: 232.

\section{Caprom, A. M., and M. J. Radin}

1988 "Choosing family law over contract law as a paradigm for surrogate motherhood." Law, Medicine, and Health Care, 16: 34-43.

\section{Carroll, G. R., and A. Swaminathan}

2000 "Why the microbrewery movement? Organizational dynamics of resource partitioning in the U.S. brewing industry." American Journal of Sociology, 106: 715-762.

\section{Carruthers, B. G., and W. N. Espeland}

1998 "Money, meaning, and morality." American Behavioral Scientist, 41: 1384-1408.

\section{Chan, C. S.-c.}

2009a "Creating a market in the presence of cultural resistance: The case of life insurance in China." Theory and Society, 38: 271-305.

2009 b "Invigorating the content in social embeddedness: An ethnography of life insurance transactions in China." American Journal of Sociology, 115 (3): 712-54. 
Darr, A.

2006 Selling Technology: The Changing Shape of Sales in an Information Economy. Ithaca, NY: Cornell University Press.

\section{Dasgupta, N.}

2004 "Unclaimed bodies at the anatomy table." Journal of the American Medical Association, 291: 122.

\section{Davis, R.}

2004 "There's money in the business of body parts: 'body brokers' find a market - And threaten medical gains." USA Today: A.01, April 07.

\section{Deephouse, D. L., and M. C. Suchman}

2008 "Legitimacy in organizational institutionalism." In R. Greenwork, C. Oliver, R. Suddaby, and K. Sahlin-Andersson (eds.), The Sage Handbook of Organizational Institutionalism: 49-77. London: Sage.

Delmonico, F. L., R. Arnold, N. Scheper-Hughes, L. A. Siminoff, J. Kahn, and S. J. Youngner

2002 "Ethical incentives - not payment - for organ donation." New England Journal of Medicine, 346: 2002-2005.

\section{de Certeau, $M$.}

1988 The Practice of Everyday Life. Berkeley, CA: University of California Press.

\section{de Michelis, A.}

2009 "OECD Economics Department working paper: Overcoming the financial crisis in the United States." Paris: Organisation for Economic Co-operation and Development.

\section{DiMaggio, P. J., and W. W. Powell}


1983 "The iron cage revisited: Institutional isomorphisms and collective rationality in organizational fields." American Sociological Review, 48: 147-160.

\section{Dobbin, F., J. R. Sutton, J. W. Meyer, and W. R. Scott}

1993 "Equal-opportunity law and the construction of internal labor-markets." American Journal of Sociology, 99: 396-427.

\section{Douglas, $M$.}

1986 How Institutions Think. Syracuse, NY: Syracuse University Press.

2002 Purity and Danger: An Analysis of Concepts of Pollution and Taboo. New York:

Routledge Classics.

\section{Dowling, J., and J. Pfeffer}

1975 "Organizational legitimacy: Social values and organizational behavior." Pacific Sociological Review, 18: 122-136.

\section{Durkheim, E.}

1964 The Division of Labor in Society. Glencoe, IL: Free Press.

1973 Emile Durkheim on Morality and Society. Chicago: University of Chicago Press.

\section{Durkheim, E., and M. Mauss}

1903 "De quelques formes primitives de classification: Contribution à l'étude des représentations collectives." Année Sociologique, 6: 1-72.

\section{Edelman, L. B.}

1990 "Legal environments and organizational governance: The expansion of due process in the American workplace." American Journal of Sociology, 95: 1401-1440.

\section{Elias, $\mathbf{N}$.}

2007 The Genesis of the Naval Profession. Dublin: University College Dublin Press. 


\section{Ertman, M. M.}

2009 "For both love and money: Viviana Zelizer's The Purchase of Intimacy." Law and Social Inquiry, 34: 1017-1037.

\section{Espeland, W. N., and M. L. Stevens}

1998 "Commensuration as a social process." Annual Review of Sociology, 24: 313344.

Fiske, A. P., and P. E. Tetlock

1997 "Taboo trade-offs: Reactions to transactions that transgress the spheres of justice." Political Psychology, 18: 255-297.

\section{Fligstein, $\mathbf{N}$.}

2002 The Architecture of Markets: An Economic Sociology of Twenty-first-century Capitalist Societies. Princeton, NJ: Princeton University Press.

\section{Fourcade-Gourinchas, M., and K. Healy}

2007 "Moral views of market society." Annual Review of Sociology, 22: 285-311.

\section{Fourcade, M.}

2007 "Theories of markets and theories of society." American Behavioral Scientist, 20: 1015-1034.

\section{Freidson, E.}

1970 Professional Dominance: The Social Structure of Medical Care. New York: Atherton.

1994 Professionalism Reborn: Theory, Prophecy, and Policy. Chicago: University of Chicago Press.

\section{Gawande, A.}


2002 Complications: A Surgeon's Notes in an Imperfect Science. New York: Henry Holt.

Gieryn, T. F.

1983 "Boundary-work and the demarcation of science from non-science: Strains and interests in professional ideologies of scientists." American Sociological Review, 48: 781-795.

1999 Cultural Boundaries of Science: Credibility on the Line. Chicago: University of Chicago Press.

\section{Glaser, B., and A. L. Strauss}

1967 The Discovery of Grounded Theory. Chicago: Aldine.

\section{Golden-Biddle, $K$.}

2001 Grounded Theory in Management Research. London: Sage.

\section{Goodwin, M.}

2006 Black Markets: The Supply and Demand of Body Parts. New York: Cambridge University Press.

\section{Granovetter, M., and R. Swedberg}

1992 The Sociology of Economic Life. Boulder, CO: Westview Press.

\section{Gross, N.}

2009 "A pragmatic theory of social mechanisms." American Sociological Review, 74: 358-379.

\section{Hallett, T., and M. J. Ventresca}

2006 "Inhabited institutions: Social interactions and organizational forms in Gouldner's Patterns of Industrial Bureaucracy." Theory and Society, 35: 213-236. 


\section{Harrington, D. E., and E. A. Sayre}

2006 "Paying for bodies, but not for organs." Regulation, 29: 14-19.

\section{Healy, $\mathbf{K}$.}

2004 "Sacred markets and secular ritual in the organ transplant industry." In F. Dobbin (ed.), The Sociology of the Economy: 308-331. New York: Russell Sage Foundation.

\section{Hirschman, A. O.}

1982 "Rival interpretations of market society: Civilizing, destructive, or feeble?" Journal of Economic Literature, 20: 1463-1484.

\section{Hsu, G.}

2006 "Jacks of all trades and masters of none: Audiences' reactions to spanning genres in feature film production." Administrative Science Quarterly, 51: 420-450.

\section{Hudson, B. A., and G. A. Okhuysen}

2009 "Not with a ten-foot pole: Core stigma, stigma transfer, and improbable persistence of men's bathhouses." Organization Science, 20: 134-153.

\section{Hughes, E. C.}

1971 "Work and self." The Sociological Eye: Selected Papers: 338-347. Chicago and New York: Aldine-Atherton.

\section{Jensen, M. C.}

2010 "Legitimizing illegitimacy: How creating market identity legitimizes illegitimate products." Research in the Sociology of Organizations, 31: 39-80.

\section{Johnson, $\mathbf{V}$.}

2008 Backstage at the Revolution: How the Royal Paris Opera Survived the End of the Old Regime. Chicago: University of Chicago Press. 


\section{Kaplan, S.}

2008 "Framing contests: Strategy making under uncertainty." Organization Science, 19: 729-752.

\section{Kellogg, K. C.}

2009 "Operating room: Relational spaces and microinstitutional change in surgery." American Journal of Sociology, 115: 657-711.

\section{Kennedy, M. T.}

2008 "Getting counted: Markets, media, and reality." American Sociological Review, 73: 270-295.

\section{Kennedy, M. T., and P. C. Fiss}

2009 "Institutionalization, framing, and diffusion: The logic of TQM adoption and implementation decisions among U.S. hospitals." Academy of Management Journal, 52: 897-918.

\section{Khurana, R.}

2007 From Higher Aims to Hired Hands: The Social Transformation of American Business Schools and the Unfulfilled Promise of Management as a Profession. Princeton, NJ: Princeton University Press.

\section{Knorr-Cetina, K.}

1999 Epistemic Cultures: How the Sciences Make Knowledge. Cambridge, MA: Harvard University Press.

\section{Lamont, $M$.}

1992 Money, Morals, and Manners: The Culture of the French and American UpperMiddle Class. Chicago: University of Chicago Press.

2000 The Dignity of Working Men: Moralities and the Boundaries of Race, Class, and Immigration. New York: Russell Sage Foundation. 


\section{Lamont, M., and V. Molnár}

2002 "The study of boundaries across the social sciences." Annual Review of Sociology, 28: 167-195.

\section{Lave, J.}

1988 Cognition in Practice. Cambridge: Cambridge University Press.

\section{Lave, J., and E. Wenger}

1991 Situated Learning: Legitimate Peripheral Participation. Cambridge: Cambridge University Press.

\section{Leider, S., and A. E. Roth}

2010 "Kidneys for sale: Who disapproves, and why?" American Journal of Transplantation, 10: 1221-1227.

\section{Lounsbury, M.}

2001 "Institutional sources of practice variation: Staffing college and university recycling programs." Administrative Science Quarterly, 46: 29-56.

\section{Lucas, L.}

2006 "Past scandals spur programs to change." Press-Enterprise: A07, September 23.

\section{Madigan, $\mathbf{N}$.}

2004 "Inquiry widens after 2 arrests in cadaver case at U.C.L.A.", New York Times: 21, March 29.

\section{Madoff, R. D.}

2010 Immortality and the Law: The Rising Power of the American Dead. New Haven, CT: Yale University Press. 
McGraw, A. P., and P. E. Tetlock

2005 "Taboo trade-offs, relational framing, and the acceptability of exchanges." Journal of Consumer Psychology, 15: 2-15.

\section{Meyer, J. W., and B. Rowan}

1977 "Institutionalized organizations: Formal structure as myth and ceremony."

American Journal of Sociology, 83: 340-363.

\section{Miles, M. B., and A. M. Huberman}

1994 Qualitative Data Analysis. Thousand Oaks, CA: Sage.

\section{Mische, A.}

2011 "Relational sociology, culture, and agency." In J. Scott and P. Carrington (eds.), Sage Handbook of Social Network Analysis. Newbury Park, CA: Sage (forthcoming).

\section{Mitford, J.}

1998 The American Way of Death Revisited. New York: Alfred A. Knopf.

\section{National Conference of Commissioners on Uniform State Laws}

1968 "Uniform Anatomical Gift Act." Philadelphia, PA: American Bar Association.

1987 "Uniform Anatomical Gift Act." Philadelphia, PA: American Bar Association.

2006 "Uniform Anatomical Gift Act." Philadelphia, PA: American Bar Association.

\section{Needham, R.}

1973 Right and Left Essays on Dual Classification. Chicago: University of Chicago Press.

\section{Negro, G., M. T. Hannan, and H. Rao}

2010 "Categorical contrast and audience appeal: Niche width and critical success in winemaking." Industrial and Corporate Change, 19: 1397-1425. 


\section{Nelsen, B. J., and S. R. Barley}

1997 "For love or money? Commodification and the construction of an occupational mandate." Administrative Science Quarterly, 42: 619-653.

\section{O'Mahony, S., and E. Long Lingo}

2010 "Nexus work: Brokerage on creative projects." Administrative Science Quarterly, 55: 47-81.

Orr, J. E.

1996 Talking about Machines: An Ethnography of a Modern Job. Ithaca, NY: Cornell University Press.

Ortner, S. B.

1984 "Theory in anthropology since the sixties." Comparative Studies in Society and History, 26: 126-166.

\section{Pfeffer, J., and G. R. Salancik}

1974 "Organizational decision making as a political process: The case of a university budget." Administrative Science Quarterly, 19: 135-151.

\section{Phillips, D. J., and D. A. Owens}

2004 "Incumbents, innovation, and competence: The emergence of recorded jazz, 1920 to 1929." Poetics, 32: 281-295.

\section{Powell, W. W., and J. Colyvas}

2008 "Microfoundations of institutional theory." In R. Greenwood, C. Oliver, R. Suddaby, and K. Sahlin-Anderson (eds.), Handbook of Organizational Institutionalism: 276-298. London: Sage.

\section{Prentice, $\mathbf{R}$.}


2005 "The anatomy of a surgical simulation: The mutual articulation of bodies in and through the machine." Social Studies of Science, 35: 837-866.

\section{Quinn, S.}

2008 "The transformation of morals in markets: Death, benefits, and the exchange of life insurance policies." American Journal of Sociology, 114: 738-780.

\section{Radin, M. J.}

1996 Contested Commodities. Cambridge, MA: Harvard University Press.

\section{Rao, H., P. Monin, and R. Durand}

2003 "Institutional change in Toque Ville: Nouvelle cuisine as an identity movement in French gastronomy." American Journal of Sociology, 108: 795-843.

2005 "Border crossing: Bricolage and the erosion of categorical boundaries in French gastronomy." American Sociological Review, 70: 968-991.

\section{Regents of the University of California}

2008 "Request for Proposal: UCOP-DD030508." Los Angeles: University of California.

\section{Sanal, A.}

2004 "'Robin Hood' of techno-turkey or organ trafficking in the state of ethical being." Culture, Medicine, and Psychiatry, 28: 281-309.

\section{Sandel, M. J.}

2009 Justice: What's the Right Thing to Do? New York: Farrar, Straus and Giroux.

\section{Sappol, M.}

2002 A Traffic of Dead Bodies: Anatomy and Embodied Social Identity in NineteenthCentury America. Princeton, NJ: Princeton University Press. 
Satz, D.

2010 Why Some Things Should Not Be for Sale: The Moral Limits of Markets. New York: Oxford University Press.

\section{Scheper-Hughes, $\mathbf{N}$.}

2000 "The global traffic in human organs." Current Anthropology, 41: 191-224.

2006 "Alistair Cooke's bones." Anthropology Today, 22: 10-15.

\section{Scott, W. R.}

1977 "Effectiveness of organizational effectiveness studies." In P. S. Goodman and J. M. Pennings (eds.), New Perspectives on Organizational Effectiveness: 63-85. San Francisco: Jossey-Bass.

1992 Organizations: Rational, Natural, and Open Systems. Englewoods Cliff, NJ:

Prentice Hall.

2001 Institutions and Organizations. Thousand Oaks, CA: Sage.

\section{Sharp, L. A.}

2006 Strange Harvest: Organ Transplant, Denatured Bodies, and the Transformed Self. Berkeley, CA: University of California Press.

\section{Snow, D. A., and L. Anderson}

1993 Down on Their Luck: A Study of Homeless Street People. Berkeley, CA:

University of California Press.

\section{Spar, D. L.}

2006 The Baby Business: How Money, Science, and Politics Drive the Commerce of Conception. Boston: Harvard Business School Press.

\section{Stark, D.}

2009 The Sense of Dissonance: Accounts of Worth in Economic Life. Princeton, NJ: Princeton University Press. 


\section{State Anatomical Board of the State of Florida}

2006 "Body donations programs in the United States." University of Florida College of Medicine. http://www.med.ufl.edu/anatbd/usprograms.html

\section{State of New York Public Health Law}

2007 "Tissue banks and nontransplant anatomic banks." State Law Title 10 §52-11.8.

\section{Steiner, $\mathbf{P}$.}

2006 "Le don d'organe: Une typologie analytique." Revue Française de Sociologie, 47: 479-506.

Suchman, M. C.

1995 "Managing legitimacy: Strategic and institutional approaches." Academy of Management Review, 20: 571-610.

\section{Swidler, A.}

2001 Talk of Love: How Culture Matters. Chicago: University of Chicago Press.

\section{Titmuss, R.}

1971 The Gift Relationship: From Human Blood to Social Policy. New York: Vintage.

\section{Tolbert, P. S., and L. G. Zucker}

1983 "Institutional sources of change in the formal structure of organizations: The diffusion of civil service reform, 1880-1935." Administrative Science Quarterly, 28: 2239.

Trompette, $\mathbf{P}$.

2008 Le Marché des Défunts. Paris: Presses de Sciences-Po.

Van Maanen, J., and S. R. Barley 
1984 "Occupational communities: Culture and control in organizations." In B.M. Staw and L.L. Cummings (eds.), Research in Organizational Behavior, 6: 287-366. Greenwich, CT: JAI Press.

\section{Weber, K., K. L. Heinze, and M. deSoucey}

2008 "Forage for thought: Mobilizing codes in the movement for grass-fed meat and dairy products." Administrative Science Quarterly, 53: 529-567.

\section{White, H. C.}

1981 "Where do markets come from?" American Journal of Sociology, 87: 517-547.

1992 Identity and Control: A Structural Theory of Social Action. Princeton, NJ:

Princeton University Press.

2008 Identity and Control: How Social Formations Emerge. Princeton, NJ: Princeton University Press.

\section{Zelizer, V. A.}

1979 Morals and Markets. The Development of Life Insurance in the United States. New York: Columbia University Press.

1985 Pricing the Priceless Child: The Changing Social Value of Children. Princeton, NJ: Princeton University Press.

2005 "Circuits within capitalism." In V. Nee and R. Swedberg (eds.), The Economic Sociology of Capitalism: 289-322. Princeton, NJ: Princeton University Press.

2010 Economic Lives: How Culture Shapes the Economy. Princeton, NJ: Princeton University Press.

\section{Zucker, L. G.}

1986 "Production of trust: Institutional sources of economic structure, 1840-1920." In

B.M. Staw and L.L. Cummings (eds.) Research in Organizational Behavior, 8: 53-111. Greenwich, CT: JAI Press. 
${ }^{1}$ One independent venture had links with a continuing-medical-education training facility, but the majority of such ventures operate independently.

${ }^{2}$ In only one instance was the distinction between spheres described in health terms, suggesting that the safety norms adopted by the independent ventures might prove less stringent than those adopted by the academically housed programs. Hepatitis and HIV testing, for instance, were routine in both spheres.

${ }^{3}$ The scandal referred to occurred at UCLA in 2004 (see Madigan, 2004, for details).

${ }^{4}$ The main exception is the Maryland State Anatomy Board, which accepted unclaimed cadavers.

${ }^{5}$ New York Public Health Law (article 4211) specifies that unclaimed cadavers are to be delivered to "schools for study" and "schools" encompass a broad range of teaching institutions.

${ }^{6}$ An archival study of shipping invoices at a typical independent venture confirmed that for-profit companies were a major category of specimen recipients (Anteby and Hyman, 2008: 967). 
Table 1

Profile of Non-Transplant Anatomical Banks in New York, 2007

\begin{tabular}{lccl}
\hline Category & $\begin{array}{c}\text { Number of license } \\
\text { holders }\end{array}$ & $\begin{array}{c}\text { Number of in- } \\
\text { state License } \\
\text { Holders }\end{array}$ & \multicolumn{1}{c}{ Example of license holders } \\
\hline Academically housed program ${ }^{*}$ & 45 & 43 & Mercy College \\
New York University & University of Rochester \\
Independent venture & 5 & 0 & Anatomy Gifts Registry \\
& & 1 & $\begin{array}{l}\text { Life Legacy Foundation } \\
\text { Science Care }\end{array}$ \\
Office of the Chief Medical Examiner & 1 & 1 & $\begin{array}{l}\text { Bronx location } \\
\text { Queens location }\end{array}$ \\
Medical-devices manufacturer & 1 & 1 & Ellman Innovations \\
Private orthopedics practice & 1 & & Orthopedics Associates \\
\hline
\end{tabular}

* The two academically housed programs located out of state were the Maryland State Anatomy Board, housed at the University of Maryland, and the Robert Wood Johnson Medical School at the University of Medicine and Dentistry in New Jersey. 
Table 2

Details of Interviewees

\begin{tabular}{lccc}
\hline Category of interviewees & $\begin{array}{c}\text { Number of } \\
\text { interviewees }\end{array}$ & $\begin{array}{c}\text { Licensed in New } \\
\text { York State }\end{array}$ & $\begin{array}{c}\text { Located in New } \\
\text { York State* }\end{array}$ \\
\hline Academically housed programs & 38 & 24 & 23 \\
Independent ventures & 4 & 3 & 0 \\
Office of the Chief Medical Examiner & 1 & 1 & 0 \\
Industry insiders & 5 & 0 & $28(58 \%)$ \\
Total & 48 & $24(50 \%)$ \\
\hline
\end{tabular}

* Interviewees from nine of the 23 in-state-licensed and located academically housed programs were among the gatekeepers described below. 
Table 3

Overview of New York License Holders' Cadaver Trades, 2007

\begin{tabular}{lccc}
\hline $\begin{array}{l}\text { Category } \\
\text { (number of programs) }\end{array}$ & $\begin{array}{c}\text { Cadavers } \\
\text { acquired } \\
\text { independently }\end{array}$ & $\begin{array}{c}\text { Cadavers used } \\
\text { in-house }\end{array}$ & $\begin{array}{c}\text { Cadavers } \\
\text { transferred to users } \\
\text { located in New York }\end{array}$ \\
\hline Academically housed programs (45) & 1,717 & 1,455 & 500 \\
$\quad$ Out-of-state academically housed programs (2) & 571 & 266 & 31 \\
Independent ventures (5) & 3,466 & 80 & 0 \\
Office of the Chief Medical Examiner (1) & 548 & 0 & 249 \\
Other* (2) & 0 & 0 & 0 \\
Total for license holders located in New York (44) & 1,694 & 1,189 & 718 \\
Total for all license holders (53) & 5,731 & 1,535 & 749 \\
\hline
\end{tabular}

* This category included a medical device manufacturer and a private orthopedic practice, both with no activity in 2007. 
Table 4

Members of AMSNY's Anatomical Committee, 2007

\begin{tabular}{|c|c|c|c|c|}
\hline Program & $\begin{array}{c}\text { Year } \\
\text { joined }\end{array}$ & $\begin{array}{c}\text { Cadavers } \\
\text { acquired } \\
\text { independently }\end{array}$ & $\begin{array}{c}\text { Cadavers } \\
\text { used } \\
\text { in-house }\end{array}$ & $\begin{array}{c}\text { Cadavers } \\
\text { transferred to } \\
\text { users located } \\
\text { in New York }\end{array}$ \\
\hline Albany Medical College & 1988 & 239 & 70 & 180 \\
\hline Albert Einstein College of Medicine & 1979 & 53 & 63 & 0 \\
\hline Columbia University $^{*}$ & 1979 & 43 & 56 & 0 \\
\hline CUNY & 1978 & 0 & 20 & 0 \\
\hline Mount Sinai School of Medicine & 1975 & 37 & 56 & 0 \\
\hline New York Chiropractic College & 1977 & 0 & 40 & 0 \\
\hline New York College of Osteopathic Medicine & 1977 & 0 & 53 & 1 \\
\hline New York Medical College & 1975 & 30 & 40 & 2 \\
\hline New York University School of Medicine ${ }^{\dagger}$ & 1978 & 30 & 39 & 1 \\
\hline Stony Brook University Medical Center & 1980 & 74 & 72 & 2 \\
\hline SUNY at Buffalo & 1975 & 294 & 197 & 97 \\
\hline SUNY Downstate Medical Center ${ }^{*}$ & 1979 & 16 & 60 & 3 \\
\hline SUNY Upstate Medical Center & 1988 & 183 & 79 & 120 \\
\hline University of Rochester & 1980 & 136 & 80 & 63 \\
\hline Weill Cornell Medical College & 1975 & 11 & 50 & 0 \\
\hline Total & & 1,146 & 975 & 469 \\
\hline
\end{tabular}

* These programs both possessed two licenses but only a single committee membership. For example, Columbia University's Department of Anatomy and Cell Biology and its Department of Orthopedic Surgery had separate licenses, but only one representative of Columbia University sat on the Committee. †New York University's College of Dentistry had a separate AMSNY membership but did not report activity in 2007. 
Table 5

Comparison of Main Practices of Trade

\begin{tabular}{|c|c|c|c|}
\hline $\begin{array}{l}\text { Dimensions of } \\
\text { comparison }\end{array}$ & $\begin{array}{l}\text { Reminder of the legal } \\
\text { provision }\end{array}$ & $\begin{array}{l}\text { Practices most academically housed } \\
\text { programs' staff perceive as legitimate }\end{array}$ & $\begin{array}{c}\text { Practices most independent ventures' staff } \\
\text { perceive as legitimate }\end{array}$ \\
\hline Payments and profits & $\begin{array}{l}\text { Reasonable payment to allay } \\
\text { procurement costs is legal. }\end{array}$ & $\begin{array}{l}\text { Requesting reimbursement by the user of only } \\
\text { the procurement costs. }\end{array}$ & $\begin{array}{l}\text { Making a profit by asking user to reimburse } \\
\text { costs above the procuring costs. }\end{array}$ \\
\hline Consent & $\begin{array}{l}\text { Potential donors, families, } \\
\text { and other identified parties } \\
\text { (e.g., a medical examiner) } \\
\text { can consent to a donation. }\end{array}$ & $\begin{array}{l}\text { Obtaining donors' direct consent to secure } \\
\text { donations. }\end{array}$ & $\begin{array}{l}\text { Obtaining families' consent (without donors' } \\
\text { direct consent) to secure donations. }\end{array}$ \\
\hline Intended use & $\begin{array}{l}\text { The law provides no explicit } \\
\text { guidelines on use for } \\
\text { educational and research } \\
\text { purposes. }\end{array}$ & $\begin{array}{l}\text { Prioritizing specimen-users' needs by: } \\
\text { - Serving medical students' anatomical needs } \\
\text { first, particularly the needs of first-year } \\
\text { medical students; } \\
\text { - Serving the anatomical needs of other } \\
\text { health-related medical professionals once } \\
\text { medical students' needs are served; } \\
\text { - Serving continuing-education anatomical } \\
\text { needs once students' needs are served; } \\
\text { - Serving medical research anatomical needs; } \\
\text { - Not serving the anatomical needs of for- } \\
\text { profit companies. }\end{array}$ & $\begin{array}{l}\text { Serving all medical-education and training } \\
\text { anatomical needs, including the needs of for- } \\
\text { profit companies. }\end{array}$ \\
\hline $\begin{array}{l}\text { Integrity of the } \\
\text { cadaver }\end{array}$ & $\begin{array}{l}\text { The law provides no explicit } \\
\text { guidelines on the integrity of } \\
\text { a cadaver. }\end{array}$ & $\begin{array}{l}\text { Refraining from dissecting a cadaver prior to } \\
\text { use. }\end{array}$ & $\begin{array}{l}\text { Dissecting a cadaver upon receipt and prior } \\
\text { to use to distribute parts to multiple users. }\end{array}$ \\
\hline
\end{tabular}

